\title{
Influence of maturity stages and post-harvest ripening on seed quality in chilli genotypes
}

\author{
Nagaraj Hullur ${ }^{1}$, Devaraju ${ }^{2}$, P.J. Radha*1 and B.N. Venkata Chalapathy ${ }^{1}$ \\ ${ }^{1}$ University of Agricultural Sciences, GKVK, BENGALURU (KARNATAKA) INDIA \\ Email : radhabn29@gmail.com \\ ${ }^{2}$ College of Sericulture, Chinthamani, KOLAR (KARNATAKA) INDIA \\ *Author for Correspondence \\ Research chronicle : Received : 04.12.2013; Revised : 10.04.2015; Accepted : 23.04.2015
}

SUMMARY :

The present study was conducted at Department of Seed Science and Technology, University of Agricultural Sciences, Gandhi Krishi Vignana Kendra, Bangalore during 2011-12 to reveal the influence of maturity stages and post-harvest ripening on seed quality among ten (Bhut jolokia, Merkera local, Sweet baccatum, Gandhari, Biligiri local, Majjige menasu, Chinense habanero, Hot cherry, Cherry pepper and Shivani) chilli genotypes belonging to Capsicum chinense, C. frutescence and C. annuиm. The results revealed that among maturity stages, fruits harvested at red ripe stage and subjected for 20 days post-harvest ripening $\left(\mathrm{M}_{4}\right)$ has recorded higher seed quality parameters viz., 1000 seed dry weight $(6.95 \mathrm{~g})$, seed germination $(66.0 \%)$, seedling length $(9.9 \mathrm{~cm})$, seedling dry weight $(1.50 \mathrm{mg})$, seedling vigour index-I (748), total dehydrogenase activity (1.314), $\alpha$-amylase activity $(34.9 \mu \mathrm{g}$ maltose $\left.\mathrm{ml}^{-1} \mathrm{~min}^{-1}\right)$ and field emergence $(56.0 \%)$. Also minimum electrical conductivity $\left(1.743 \mathrm{dSm}^{-1}\right)$ and moisture content of fresh seed $(10.93 \%)$ was noticed.

KEY WORDS : Maturity stages, Seed quality, $\alpha$-amylase activity, Total dehydrogenase activity

How to cite this paper : Hullur, Nagaraj, Devaraju, Radha, P.J. and Chalapathy, B.N. Venkata (2015). Influence of maturity stages and post-harvest ripening on seed quality in chilli genotypes. Internat. J. Proc. \& Post Harvest Technol., 6 (1) : 19-25. 